THE JOURNAL OF CHEMICAL INDUSTRY, TOKYO, JAPAN.

Vol. XXVII, No. $5 . \quad$ MAY, $1924 . \quad$ No. 315.

\author{
ABSTRACTS FROM THE ORIGINAL PAPERS.
}

\title{
ON THE MECHANISM OF THE FORMATION OF BLEACHING POWDER.
}

\author{
By Shuichiro Ochi, Kōgakushi.
}

(Received February 21, 1924.)

By the part one the author has criticised the constitutional formula and the theory of the formation of bleaching powder, which had been published by such authorities as G. Lunge, H. Ditz, W. V. Tiesenholt and F. Winteler.

By the part two the author has argued the mechanism by which slaked lime is chlorinated to bleaching powder. The theory is thus in brief: hydrochloric and hypochlorous acids are first formed owing to the hydrolysis of chlorine which dissolves to the water adhering to lime, its action is being accelerated by $\mathrm{OH}^{\prime}$. The acids neutralize lime, and the just finished bleaching powder may therefore contain $\mathrm{Ca}(\mathrm{OCI}) \mathrm{Cl}, \mathrm{CaCl}_{2}, \mathrm{Ca}(\mathrm{OCl})_{2}$, $\mathrm{Ca}(\mathrm{OH}) \mathrm{Cl}, \mathrm{Ca}(\mathrm{OH})(\mathrm{OCl})$, free $\mathrm{HOCI}$ and water, as Winteler has explained. But these compounds dissolve together in one mass consisting a solid solution, and from this solid solution the crystal which is represented by a constitutional formula $\mathrm{Ca}(\mathrm{OCl}) \mathrm{Cl} . \mathrm{H}_{2} \mathrm{O}$ crystallizes out. The author has found that the crystallization is greatly retarded by the increase of the water content and the elevation of temperature at the chlorination.

From the point of view that the velocity of the reaction $\mathrm{Ca}(\mathrm{OCl}) . \mathrm{H}_{2} \mathrm{O}$ $+\mathrm{xH}_{2} \mathrm{O} \rightarrow \mathrm{Ca}(\mathrm{OH})_{2}+\mathrm{Cl}_{2}+\mathrm{xH}_{2} \mathrm{O}$ is not so great, the author has considered that the free lime which is contained in bleaching powder is not originated by the decomposition of bleaching powder, but by the escape of chlorination. He has therefore expected that the pure $\mathrm{Ca}(\mathrm{OCl}) \mathrm{Cl} . \mathrm{H}_{2} \mathrm{O}$. will be 
made, though it may not be a stable compound, if the slaked lime is properly made.

(The Tokyo Imperial Industrial Laboratory.)

\section{SYNTHESIS OF NATRIUM CYANIDE FROM NATRIUM SULPHATE OR NATRIUM CHLORIDE, AND ALKALINE EARTH CARBONATE, CARBON, AND FREE NITROGEN. (Report I.)}

\section{By Ryosaburo Hara, Kögakushi, and Hikoziro Miura.}

(Received March 24, 1924.)

In the ordinary methods of the synthesis of $\mathrm{NaCN}$ from $\mathrm{Na}_{2} \mathrm{CO}_{3}, \mathrm{C}$, and free $\mathrm{N}_{2}$, using iron as catalyser, it has been difficult or practically impossible to substitute some cheaper natrium salts such as $\mathrm{Na}_{2} \mathrm{SO}_{4}$ or $\mathrm{NaCl}$ for $\mathrm{Na}_{2} \mathrm{CO}_{3}$. The authors have suggested and proved experimentally that $\mathrm{Na}_{2} \mathrm{SO}_{4}$ or $\mathrm{NaCl}$ with the addition of alkaline earth carbonate or oxide can be substituted for $\mathrm{Na}_{2} \mathrm{CO}_{3}$. In this report, the experiments have been carried out chiefly coucerning $\mathrm{Na}_{2} \mathrm{SO}$, and $\mathrm{BaCO}_{3}$, or $\mathrm{NaCl}$ and $\mathrm{BaCO}_{3}$, as the substituents.

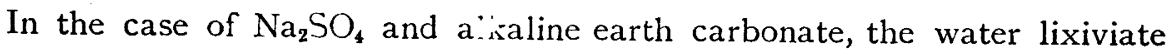
of the reacted mass contains some amount of ferrocyanide and thiocyanate besides cyanide. In the dry reacted mass, however, cyanide only, although sometimes accompanied with a small amount of cyanamide, is present. The following reacting conditions have been found to be the suitable ones.

\begin{tabular}{|c|c|c|c|c|c|c|c|c|}
\hline \multirow{2}{*}{$\begin{array}{c}\text { Tempera- } \\
\text { ture } \\
\operatorname{in}^{2} \mathrm{C}\end{array}$} & \multirow{2}{*}{$\begin{array}{l}\text { Time } \\
\text { n min. }\end{array}$} & \multirow{2}{*}{$\begin{array}{c}\mathrm{N} 2 \\
\text { in mol. }\end{array}$} & \multirow{2}{*}{$\begin{array}{l}\mathrm{NaCl} \text { or } \\
\mathrm{Na}_{2} \mathrm{SO}_{4} \\
\text { in mol. }\end{array}$} & \multirow{2}{*}{$\begin{array}{l}\mathrm{BaCO}_{3} \\
\text { in mol. }\end{array}$} & \multirow{2}{*}{$\begin{array}{c}\mathrm{C} \\
\text { in mol. }\end{array}$} & \multirow{2}{*}{$\begin{array}{c}\mathrm{Fe} \\
\text { in mol. }\end{array}$} & \multicolumn{2}{|c|}{ Yield in $\%$} \\
\hline & & & & & & & $\begin{array}{l}\text { Cyana- } \\
\text { mide }\end{array}$ & Cyanide \\
\hline 1000 & 150 & 10 & $\mathrm{I}\left(\mathrm{Na}_{2} \mathrm{SO}_{4}\right)$ & I. 2 & 10 & 0.5 & 4.6 & 85.5 \\
\hline$"$ & ", & $"$ & $2(\mathrm{NaCl})$ & " & $"$ & $"$ & 4.9 & 72.3 \\
\hline
\end{tabular}

The yields are expressed in $\%$ of the $\mathrm{Na}$ in the $\mathrm{Na}_{2} \mathrm{SO}_{4}$ and $\mathrm{NaCl}$ originally used, which has been changed into $\mathrm{NaCN}$, the total cyanide in the 
reacted mass being assumed to be $\mathrm{NaCN}$.

\section{ON THE OCCURRENCE OF A TETRADECYLENIC ACID IN TOHAKU OIL.}

\section{By Mitsumaru Tsujimoto, Kogakuhakushi.}

(Received March 27, 1924.)

$500 \mathrm{~g}$ of the methyl esters of the mixed fatty acids of a sample of Tōhaku oil was fractionated under $15 \mathrm{~mm}$ pressure. The fraction boiling at $158-167^{\circ} \mathrm{C}$ (yield about $1.7 \%$ ) was saponified and after the extraction of the unsaponifiable matter, the fatty acids were changed to barium soaps. The barium soaps were treated with ether; the ether solution was decomposed with hydrochloric acid and the free acid was obtained as a pale yellow liquid. The acid had the following properties:-

sp. gr. $\left(15 / 4^{\circ} \mathrm{C}\right) \quad 0.9017$ Iodine value IOg. 1

Neutr. value $249.4 \quad$ Ref. index $\left(15^{\circ} \mathrm{C}\right) \quad 1.4562$

The substance has been confirmed to be a tetradecylenic acid $\mathrm{C}_{\mathbf{1 4}} \mathrm{H}_{26} \mathrm{O}_{2}$. On hydrogenation the acid yielded myristic acid.

The acid is probably identical with the tetradecylenic acid which the author has already isolated from sperm and dolphin oils,

(Tokyo Imperial Industrial Laboratory.)

\section{A SATURATED HYDROCARBON IN SHARK LIVER OILS.}

By Yoshiyuki Toyama, Kögakushi.

(Received March 8, I924.)

I. A saturated hydrocarbon, isoöctadecane, which had been formerly tested by M. Tsujimoto in only one sample of basking shark liver oil and been regarded by him as an abnormal constituent of that liver oil, was now isolated by the present author from a number of samples of liver oils from Rabukazame (Chlanydoselachus anguincus Garman), basking shark, Yoroizame (Scymnorhinus licha), Ōaka-aizame, Heratsunozame (Acanthidium 
cglantina) and commercial Aizame and Kurozame oils. The liver oils from Kimbeizame (Lepidorlinus kimbei Tanaka), Birōdozame (Zameus squamulosus) and another sample of Rabukazame oil seemed to contain a minute amount of it. Another sample of Birōdozame oil was the only case in which its occurrence was doubtful. Thus the hydrocarbon appears as a normal constituent in a small amount in various kinds of squalene containing shark liver oils. The name pristane was proposed to it.

2. Some properties of purified pristane were determined.

3. Crude pristane obtained by fractional distillation of the oil was generally accompanied by a small amount of unsaturated hydrocarbons. But it is doubtful whether they are original constituents of the oil or not. They may perhaps be decomposition products of squalene.

\section{THE NITRATES OF OXY- AND HYDRO-CELLULLOSES AND CEllulose hydRATE.}

\section{Katsumoto Atsuki, Kōgakuhakushi.}

(Received January 23, 1924.)

I. By nitrating various oxycelluloses, prepared from normal cottun cellu lose by bleaching with bleaching powder solution under various conditions, it is observed that with the increase in the copper number of the oxycelluloses, yield decreases, nitrogen content decreases, solubility increases, and viscosity decreases, progressivcly" and proportionately, but that when the copper number reaches about IO, there occurs a sudden fall in nitrogen content, and the grave changes in the other properties.

2. The oxidation of cellulose seems to proceed in two stages at least. In the first stage, the oxidation of hydroxyl groups into aldehyde or ketonic groups, and the disintegration of the molecular complex of cellulose into the smaller multiples of the cellulose uncleus $\left(\mathrm{C}_{3}\right.$-unit), seem to be predominated, but in the sccond stage, the oxidation of aldehyde or ketonic group into carboxyl group, and the split of the cellulose nucleus into the smaller compounds containing less carbon atoms than 6 , appears to be predominated. 
3. By determining the rate of the decrease in the Abel heat test and ignition point of various oxycellulose nitrates containing the various amounts of sulphuric acid, by exposing to the heat at $60-65^{\circ} \mathrm{C}$. for a given period; it is observed that the more oxidized cellulose nitrate is more sensible: to the decomposing action of acid, but that when the content of the acid is reduced to a trace, the decrese in the stability becomes nearly equal with each oxycellulose nitrate: But the cellulose nitrate, produced from the oxycellulose, obtained by the second stage of oxidation, shows always low stability.

4. In order to obtain a stable product from oxycellulose nitrate, by: bringing the content of sulphuric acid to a given minimum amount, a thorough boiling is required. The oxycellulose nitrate, produced from a deeply oxidized cellulose, however, can never be stabilized, which appears to be caused by that this oxycellulose nitrate is not a derivative of cellulose but is a quite new substance of being unstable.

5. A number of oxycellulose nitrates has been prepared from normal cellulose as well as various oxycelluloses, and stabilized by boiling until the content of sulphuric acid and the ignition point have become the same. From each cellulose nitrate, the film containing about 16.6 per cent camphor (calculated) has been prepared, and submitted to heating at $85^{\circ} \mathrm{C}$. It is obsereved that the more oxidized cellulose nitrate gives the more brittle and more unstable celluloid. It seems that the gel-structure of celluloid has an intimate relation not only to the mechanical properties but also to the stability of celluloid.

5. By examining the action of sodium hydroxide and sodium sulphite solutions on cellulose nitrates, prepared from various oxycelluloses, it is observed that the former saponifies both the oxy- and normalcellulose nitrate, while the latter dissolves the deeply oxidized cellulose nitrates, without attacking the normal cellulose nitrate, if the concentration of the solution and the duration of boiling are regulated. If, therefore, a sample of cellulose nitrate is composed of normalcellulose and oxycellulore nitrate, then the latter can be eliminated in a more or less degree by the fractional resolution with sodium sulphite solution at boiling. The condition of treatment is to be regulated according to the properties of the oxycellulose 


\section{nitrate contained.}

7. The cellulose nitrate from mercerized cotton gives a higher solubility, lower viscosity, higher content of sulphuric acid, and higher copper number of the recovered cellulose, than that from now mal cotton, though the copper numbers of both the cotton are the same. The sulphuric acid retained by the mercerized cellulose nitrate is easily eliminated by boiling, and therefore the stability is hardly affected by mercerization. It is to be considered that cellulose hydrate suffers a more hydrolysis during nitration than normal cellulose, and therefore, the nitrating condition must be regulated.

(Department of Applied Chemistry, Faculty of Engineering, Tokyo

Imperial University.)

\section{The preparation of Cellulose acetate.}

By Seisuke Kodama, Rigakushi.

(Received February 4, 1924.)

Sulphuric acid, zinc chloride and chloro-acetic acids have been most popularly employed as catalysts of the acetylation of cellulose, but many of them possess the disadvantage that they give coloured or cloudy solutions owing to the decomposition and degradation of the cellulose ester. I have found the following suitable conditions for acetylation and ripening of cellulose acetate.

I. The moisture present in cellulose exerts a marked influence upon the speed and causes difficulty in controlling the acetylation. Reduction tó $\mathrm{I}-\mathrm{I} .5 \%$ by drying is necessary.

2. The amount of glacial acetic acid as a diluent at the acetylation is $400-600$ parts for 100 parts by weight of bone dry cellulose.

3. By using a mixture of sulphuric acid or sulphates which liberate sulphuric acid at the acetylation, and hydrochloric acid or chlorine compounds which liberate hydrochloric acid similarly, the acetylation proceeds at any temperature and is easy to be controlled. The amount of acetic 
anhydride can be decreased almost to the theoretical degree.

4. Concentration of acetic acid at the ripening is $80.85 \%$ by weight.

5. By using sulphuric acid, hydrochloric acid and zinc chloride at the ripening, satisfactory results are obtained. For example a mixture of $7 \mathbf{g}$. water, $7 \mathrm{~g}$. glacial acetic acid, and $0.9 \mathrm{~g}$. sulphuric acid (sp. gr. 1.84) is slowly added to the 7.5 parts of cellulose acetate in solution in the acetylating mixture and heated at $42^{\circ} \mathrm{C}$. After 3 hours the product becomes soluble in acetone.

(The Tokyo Imperial Industrial Laboratory)

\section{STUDIES ON NAPHTHENIC ACIDS. V. NAPHTHENIC ACIDS DERIVED FROM AKITA KEROSENE DISTILLATE.}

By Yoshio Tanaka, Kögakuhakushi, and Shoichiro Nagai, Kögakushi.

(Received March 20, 1924.)

In the first paper (Kogyo Kwagaku Zasshi or The Journal of Chemical Industry, Japan, 1922, 25, 1031-1044), the authors reported the studies on naphthenic acids from a waste lye produced in the refining of a petroleum distillate of $25-26^{\supset} \mathrm{B} \dot{3}$. ("Neutral Distillate") from Akita-Kurokawa crude oil. In the second paper (Ibid., 1923, 26, 309-316), the authors reported that the three main constituents, $\mathrm{C}_{13} \mathrm{H}_{24} \mathrm{O}_{2}, \mathrm{C}_{14} \mathrm{H}_{25} \mathrm{O}_{2}$ and $\mathrm{C}_{15} \mathrm{H}_{28} \mathrm{O}_{2}$ have been isolated from the above naphthenic acids, and these had the higher specific gravities than those of foreign origin. And further, in their third paper (Ibid., 1923, 26, 1115-1123.), naphthenic acids from refining of a kerosene distillate from Kubiki (Niigata Prefecture) crude oil were studied. The specific gravities of the naphthenic acids and their methyl esters of the latter origin were considerably smaller than those of the former, being nearly equal to those of foreign origins.

The present report describes a further investigation upon the naphthenic acids from a waste lye produced in the refining of kerosene distillate from probably Katsurane (Akita Prefecture) origin. The results are briefly summarized as follows; 
(I) By acidifying the waste lye, a crude mixture of acid substances was obtained, having a specific gravity $\left(d_{4}^{15^{\circ}}\right)$ I.1 I 28 , a refractive index $\left(n b^{5^{\circ}}\right)$ 1.4195 and an acid value 156.7 . From this, the authors obtained, by a : new extraction method, crude naphthenic acids with the yield of 8.6 per cent, having a specific gravity $\left(d_{4}^{15^{5}}\right) 0.9747$, a refractive index $\left(n_{1} 5^{\circ}\right)$ I 4796 and an acid value 23r.8.

3. (2) The crude naphthenic acids have a range of distilling temperatures nearly equal to that of crude naphthenic acids from the Kurokawa "Neutral Distillate" (loc. cit.) and about 83 per cent of the crude naphthenic acids distils at $170^{\circ}-220^{\circ} \mathrm{C} .\left(8.9-9.0 \mathrm{~mm}\right.$.). The fractions above $200^{\circ} \mathrm{C}$. show the lower specific gravities than those of the preceding fractions.

(3) The mixed methyl esters of the naphthenic acids have a specific gravity $\left(\alpha_{4}^{1} 5^{\circ}\right)$ of 0.9470 and a refractive index $\left(n_{D} 5^{\circ}\right)$ of 1.4676 . Abqut 70 per cent of the esters distils at $130^{\circ}-180^{\circ} \mathrm{C}$. $(8.9-9.0 \mathrm{~mm}$ ), this range being equal to that of the main parts of the esters of naphthenic acids from Kurokawa "Neutral Distillate". The fractions absve $200^{\circ} \mathrm{C}$. show also the decreasing specific gravities.

i..... (4). By saponifying the mixed esters, a mixture of pure naphthenic acids was obtained. It has a specific gravity $\left(d_{4}^{15^{5^{\circ}}}\right)$ of 0.9766 , a refractive index $\left(n_{\nu}^{15^{\circ}}\right)$ of 1.4790 and an acid value of 230.2. About 86 per cent distils at $170^{\circ}-220^{\circ} \mathrm{C}$. $\left(8.9-9.0 \mathrm{~mm}\right.$.). The higher fractions above $200^{\circ} \mathrm{C}$. show again lower specific gravities than those of the preceding fractions, indicating; in the higher fractions, the presence of the naphthenic acids of low specific gravities. By comparing the above mixed pure naphthenic acids: with those of Kurokawa origin (loc. cit.) the distilling range of the main parts is nearly equal and the acid value is a little smaller, but the specific gravity (0.97) of the former is considerably smaller than that (0.99) of itbe latter. (Department : of Applied Chemistry, Faculty of Engineering, Tokyo Imperial University.). 


\section{ON THE LACCASE OF JAPANESE LAC. (FIRST REPORT.)}

By Shigeru Hirano, Kögrakuslii.

(Received April 9, 1924.)

The author has investigated the gum and nitrogenous matter obtained from the juice of Rus i'rnificra which was collected in Yechigo Province under special care. The gum was obtained from that portion of the juice which is insoluble in alcohol and soluble in cold water, and gave the following composition on elementary analysis:

$$
\text { C } 44.47 \% \text { H } 7.87 \% \text { N } 1.68 \% \text { ash } 4.24 \%
$$

G. Bertrand assumes nitrogen as protein nature, and as one of the constituents of the laccase of the lac juice. According Tschirch and Stevens (Arch. dir I'larm., I905, 243, 504) this oxydase of Japanese lac shows the pyrrole reaction, and not Lassaigne's nitrogen reaction. But the author has observed the both reactions.

The author has examined also the carbohydrates of the gum. (a) Distillating with $\mathrm{HCl}$ gave distillate which showed furfurol reaction and gave $13.63 \%$ of phloroglucide. (b) Oxidizing with $\mathrm{HNO}_{3}$, extracting the precipitate with $\left(\mathrm{NH}_{4}\right)_{2} \mathrm{CO}_{3}$, evaporating the solution, and reprecipitating with $\mathrm{HNO}_{3}$ gave $35.36 \%$ of mucic acid.

The nitrogenous matter obtained from that portion of the juice which is insoluble in alcohol and in water, gave the following composition on elementary analysis :

$$
\text { C } 64.48 \% \quad H \quad 9.19 \% \quad \mathrm{~N} \quad 6.89 \% \quad \text { ash } 3.55 \%
$$

In this case also both pyrrole and Lassaigne's reactions were observed. (Tokyo Imperial Industrial Laboratory.) 